\title{
Soil Shrinkage and Consolidation Study on Flood Embankments in Swamp Irrigation Areas (Case Study: Tulang Bawang - Indonesia)
}

\author{
Lusmeilia Afriani", Gatot Eko Susilo, Sri Nawangrini, Iswan \\ Department of Civil Engineering, Universitas Lampung, Bandar Lampung, 35145, Indonesia
}

Received September 4, 2020; Revised November 4, 2020; Accepted November 11, 2020

\section{Cite This Paper in the following Citation Styles}

(a): [1] Lusmeilia Afriani, Gatot Eko Susilo, Sri Nawangrini, Iswan, "Soil Shrinkage and Consolidation Study on Flood Embankments in Swamp irrigation Areas (Case Study: Tulang Bawang - Indonesia)," Civil Engineering and Architecture, Vol. 8, No. 6, pp. 1225 - 1233, 2020. DOI: 10.13189/cea.2020.080607.

(b): Lusmeilia Afriani, Gatot Eko Susilo, Sri Nawangrini, Iswan (2020). Soil Shrinkage and Consolidation Study on Flood Embankments in Swamp irrigation Areas (Case Study: Tulang Bawang - Indonesia). Civil Engineering and Architecture, 8(6), 1225 - 1233. DOI: 10.13189/cea.2020.080607.

Copyright $\bigcirc 2020$ by authors, all rights reserved. Authors agree that this article remains permanently open access under the terms of the Creative Commons Attribution License 4.0 International License

\begin{abstract}
Research in this paper discusses shrinking and consolidation of flood embankments soil in swamp irrigation areas. The flood embankments are made from swampy soil materials. The focus of this research is the reduction of dyke embankment height that occurs due to soil shrinkage and soil consolidation. Investigations about the time of consolidation and land subsidence that occurred on the embankment at certain periods after the embankment established were also carried out in this study. The research sites are some swamp irrigation areas in the Tulang Bawang Watershed, around North-East Lampung, Indonesia. This research was carried out by conducting laboratory tests on soil samples and field observations on the reduction in height on flood embankments in the study area. The research shows that the main cause of total decrease on the embankment is due to linear shrinkage, consolidation of soil under the embankment, an immediate subsidence, and the subsidence of the embankment themselves. Their contribution to total decrease of embankment is $42.51 \%, 34.48 \%, 18.32 \%$, and $4.62 \%$, respectively. Results also indicate that the ratio between the percentages of embankment consolidation in downstream area happens faster than the one in upstream area of the river.
\end{abstract}

Keywords Shrinkage, Consolidation, Embankment, Swamp Irrigation

\section{Introduction}

Flood embankments on swamp irrigation are made by utilizing local soil by digging the soil on the right and left of the plan of the dike wall. This utilization of local soil is carried out in consideration of cost efficiency and easy access to material and technical implementation of the work [1]. On the other hand, flood protection dykes in swamp irrigation areas requires special attention in relation to the decline or depreciation that will be experienced. Scientifically, the decline of flood embankment body due to the material forming it, was rarely discussed by the public. Basically, if the reduction or depreciation is well considered in the design of the embankment, there will be cost savings in the construction process. Studies investigating the behavior of soil depreciation on flood embankments in swamp irrigation are an interesting special topic. Depreciation that occurs on expansive or soft soils that form dikes will cause a decrease in the embankment body [2]. Furthermore, the burden on the embankment will also cause a decrease in the embankment body due to consolidation on the embankment body itself and consolidation on the soil under the embankment. On the other hand, it is also necessary to consider an immediate settlement that occurs in the soil under the embankment. In addition, Kumor [3] found that the main problem in the application of geotechnique in the field was estimating depreciation due to post-consolidation on expansive soils. 
On the other hand, [4] who evaluates the volume depreciation in relation to changes in water content, suggests that the water content must also be considered together with the nature of the soil material in the volume depreciation. In principle, the shrinkage limit is defined as a condition where the land mass does not change in volume when the water content decreases [5]. For this reason, we need to know the volumetric shrinkage value $\left(V_{c}\right)$ of the soil. $V_{c}$ is the change in soil volume from initial volume until the soil no longer experiences shrinkage in the elongated direction.

In relation to the reduction, we also need to determine the linear shrinkage $\left(L_{s}\right)$, which is the decrease of soil which can occur due to the loading on it. This decrease is caused by elastic deformation of the soil in dry, wet or saturated soil conditions where the decrease does not occur with changes in water content. The magnitude of this reduction will depend on the shape and dimensions of the foundation and the type of material in which the foundation is placed [6]. In addition to the elastic deformation of the soil, the addition of a load over the surface can also cause the soil layer underneath to compress due to the release of water or air from the pore, which is called consolidation. The decline in the flood embankment will run over time. A decrease due to shrinkage (linear shrinkage) and an immediate settlement due to elastic deformation of the soil can be assumed to occur immediately. However, it needs to be examined specifically regarding the time of depreciation and the time of immediate settlement.

The research in this paper discusses the shrinking and decreasing behavior of the soil on flood dyke embankments which were made from swampy soils in swamp irrigation areas. The focus of this research is the reduction of dyke embankment height that occurs due to soil shrinkage and soil consolidation. Investigations about the time of consolidation and soil subsidence that occurred at certain periods after the embankment established were also carried out in this study. The research sites are some swamp irrigation areas in the Tulang Bawang Watershed, around North-East Lampung, Indonesia.

\section{Materials and Methods}

The soil sample used in this study is swamp soil that exists between Tulang Bawang River and Pidada River, Tulang Bawang Regency. Three soil sampling and observations were carried out at 3 places located within the scope of the Pidada River Basin. They are Aji Mesir, Batu Ampar and Rawa Ragil points. While other samples were taken at the Sumber Sari and Gedung Jaya locations, which take place within the scope of the Tulang Bawang River Basin.

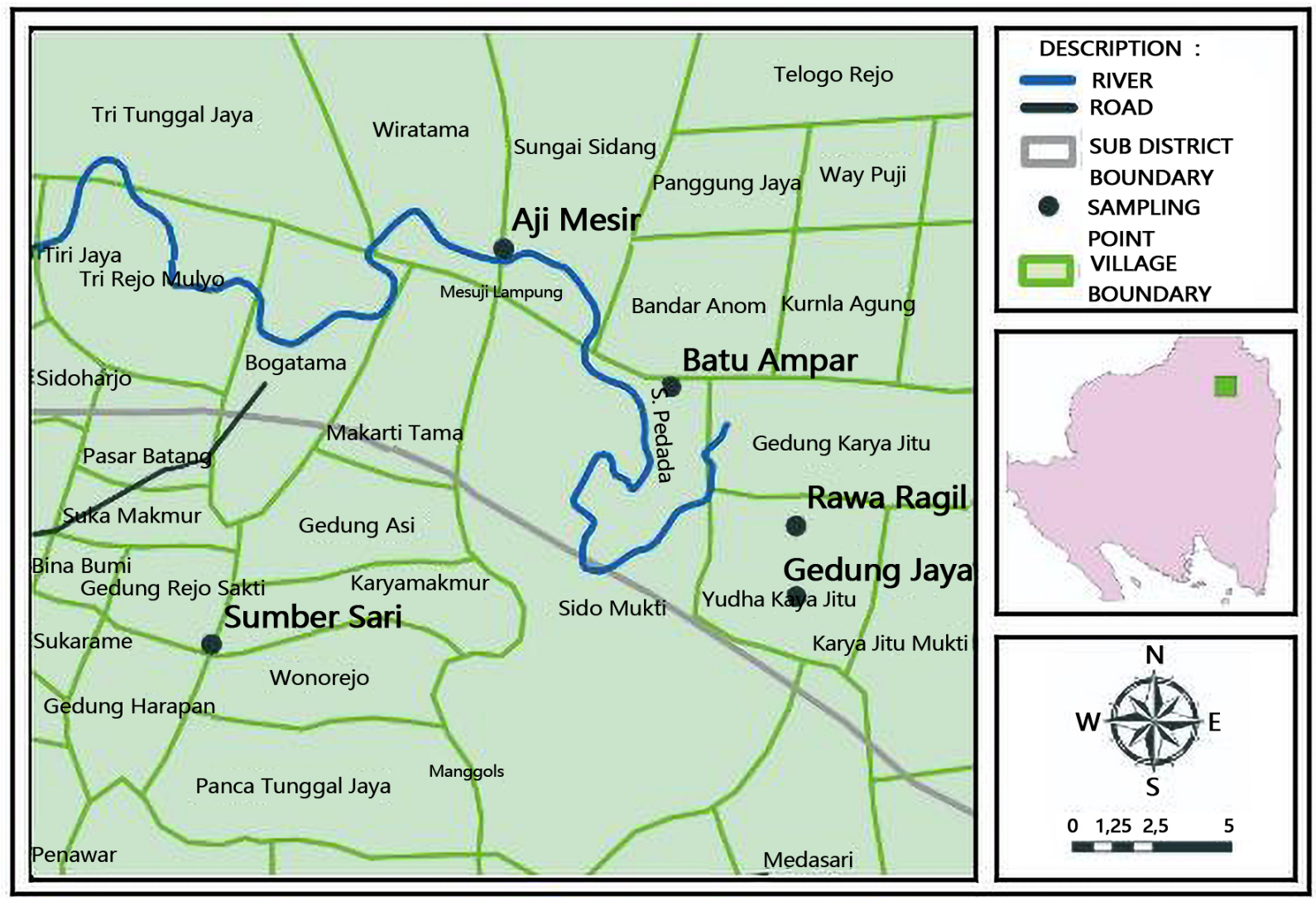

Figure 1. Study area [7] 
This research was carried out by conducting laboratory tests on soil samples and field observations on the reduction in height on flood embankments in the study area. The reduction in the height of the flood embankment to be reviewed is the settlement assumed to be caused by soil shrinkage, immediate decrease and decrease due to primary consolidation. The depth of soft soil around the study site was estimated using Cone Penetration Test. The steps undertaken to analyze the reduction in flood embankments and the time of decline are as follows:

\subsection{Calculation of Decrease due to Linear Shrinkage}

Decrease in height of embankments due to linear shrinkage can be predicted by calculating the volumetric shrinkage by conducting shrinkage and moisture content tests. Following are some of the equations used in determining the shrinkage limit, volumetric shrinkage, shrinkage ratio and linear shrinkage.

\subsubsection{Shrinkage Limit Calculation}

$$
W s=W-\frac{\left(V-V_{d}\right) \gamma_{w}}{W_{d}} \times 100 \%
$$

with,

$W_{s}=$ shrinkage limit

$W=$ the weight of the wet ground

$V=$ volume of wet soil

$V_{d}=$ dry soil volume

$\gamma_{\mathrm{w}}=$ unit weight of water content $\left(\mathrm{kg} / \mathrm{m}^{3}\right)$

$W_{d}=$ weight of dry soil

\subsubsection{Volumetric Shrinkage Calculation}

$$
V_{c}=\left(w_{0}-w_{s}\right) \times \frac{w_{d}}{V_{d} \cdot \gamma_{w}}
$$

with,

$$
\begin{aligned}
& V_{c}=\text { volumetric shrinkage } \\
& w_{0}=\text { initial water content } \\
& w_{s}=\text { shrinkage limit } \\
& W_{d}=\text { weight of dry soil } \\
& V_{d}=\text { dry soil volume } \\
& \gamma_{\mathrm{w}}=\text { unit weight of water content }
\end{aligned}
$$

\subsubsection{Linear Shrinkage Calculation}

$$
L_{s}=100 \times\left(1-\left[\frac{(100)}{\left(V_{c}+100\right)}\right]^{3}\right)
$$

with,

$$
\begin{aligned}
& L s=\text { linear shrinkage } \\
& V c=\text { volumetric shrinkage }
\end{aligned}
$$

\subsubsection{Shrinkage Ratio Calculation}

$$
\mathrm{R}=\frac{v_{c}}{w_{0}-w_{s}}
$$

with,

$$
\begin{aligned}
& R=\text { shrinkage Ratio } \\
& V_{c}=\text { volumetric Shrinkage } \\
& w_{0}=\text { initial water content } \\
& w_{s}=\text { shrinkage limit }
\end{aligned}
$$

\subsection{Calculation of Decrease due to Linear Shrinkage}

$$
S i=P \cdot B \cdot \frac{1-\mu^{2}}{E} \cdot I p
$$

with,

$$
\begin{aligned}
& S_{i}=\text { immediate decline } \\
& P I=\text { evenly distributed load } \\
& B=\text { foundation width } \\
& I P=\text { influence factor } \\
& \mu=\text { Poisson ratio } \\
& E=\text { Young modulus }
\end{aligned}
$$

\subsection{Soil Subsidence as a Result of Consolidation}

Pre consolidation pressure is the maximum overburden pressure that has ever occurred on the soil under test. If the OCR value $<1$, then the land has consolidated (decreased). The OCR value is the ratio between the pre-consolidation pressure and the current overburden pressure. To calculate the decrease due to this consolidation, we need to determine the work load, which is the flood embankment load and the soft soil load reviewed. In addition, the pore number $\left(e_{0}\right)$ and compression index $\left(C_{c}\right)$. In general, the amount of consolidation that occurs is as follows:

$$
S=\frac{H C_{c}}{1+e_{0}} \log \frac{p_{1}^{\prime}}{p_{0}}
$$

with,

$$
\begin{aligned}
& S=\text { soil subsidence due to consolidation }(\mathrm{cm}) \\
& H=\text { depth/height of land }(\mathrm{cm}) \\
& e_{0}=\text { initial pore number } \\
& C_{c}=\text { compression index } \\
& p_{1}=\text { preconsolidation pressure }=p_{0}+\Delta p \\
& p_{0}=\text { effective overburden pressure before loading }
\end{aligned}
$$

\subsection{Time of Consolidation}

At the end of the consolidation, the land was considered to have reached the degree of consolidation of U90\% with a $T_{v}$ time factor of 0.848 . This is because, after the primary consolidation, there is actually still a decline up to U100\% with a $T_{V}$ value of infinite $(\approx)$. Time of consolidation can be determined based on the following equation:

$$
\mathrm{t}=\frac{T_{v} \cdot H_{d r}^{3}}{C_{v}}
$$

with,

$t=$ consolidation time (seconds)

$T_{v}=$ time factor

$H_{d r}=$ depth of soil under consideration for consolidation (cm)

$$
C_{v}=\text { consolidation coefficient }
$$

\section{Results and discussions}

In this study, the results and discussion are a combination of laboratory test data, field measurements, calculation results and analysis, which consist of: 


\subsection{Soil Type, Physical Properties, Clay Content, and Organic Content}

Based on the USCS Method, 3 samples were of type SC (sandy loam) and $\mathrm{CH}$ (loam with high plasticity). Whereas based on the USDA [8] method, the samples are clay type. The clay content is between $36.44 \%-79.94 \%$. The more downstream of the sample location the clay content of the sample tends to be greater. Organic content of the samples ranged from $11.38 \%-22.43 \%$ and was classified as clay or soft soils [9].

Table 1. Soil type, physical properties, clay content, and organic content

\begin{tabular}{cccccc}
\hline $\begin{array}{c}\text { Physical } \\
\text { properties }\end{array}$ & $\begin{array}{c}\text { Aji } \\
\text { Mesir }\end{array}$ & $\begin{array}{c}\text { Sumber } \\
\text { Sari }\end{array}$ & $\begin{array}{c}\text { Gedung } \\
\text { Jaya }\end{array}$ & $\begin{array}{c}\text { Rawa } \\
\text { Ragil }\end{array}$ & $\begin{array}{c}\text { Batu } \\
\text { Ampar }\end{array}$ \\
\hline $\begin{array}{c}\text { Specific weight } \\
(\mathrm{Gs})\end{array}$ & 2.68 & 2.52 & 2.43 & 2.43 & 2.29 \\
\hline $\begin{array}{c}\text { Unit weight } \\
\text { volume (gr/cm }\end{array}$ ) & 1.60 & 1.39 & 1.31 & 1.32 & 1.35 \\
\hline $\begin{array}{c}\text { Mass density } \\
(\text { gr/cm }\end{array}$ & 1.61 & 1.35 & 1.32 & 1.37 & 1.40 \\
\hline $\begin{array}{c}\text { Pore number ('e) } \\
\text { Degree of }\end{array}$ & 1.27 & 1.45 & 2.05 & 1.65 & 2.47 \\
\hline $\begin{array}{c}\text { saturation (\%) } \\
\text { Water content } \\
(\%)\end{array}$ & 40.75 & 40.64 & 70.44 & 50.08 & 113.43 \\
\hline Porosity (\%) & 57.68 & 60.79 & 68.48 & 63.77 & 72.34 \\
\hline Silty clay (\%) & 36.44 & 46.53 & 47.69 & 53.97 & 79.94 \\
\hline
\end{tabular}

\subsection{Soil Settlement}

To determine the amount of settlement and decrease due to shrinkage, we need to do a shrinkage test. Volume changes due to shrinkage can be seen on the basis of volumetric shrinkage, shrinkage ratio, and linear shrinkage. Calculation of settlement of soil can be seen in the table below.

Table 2. Results of calculation of soil settlement

\begin{tabular}{cccccc}
\hline $\begin{array}{c}\text { Physical } \\
\text { properties }\end{array}$ & $\begin{array}{c}\text { Aji } \\
\text { Mesir }\end{array}$ & $\begin{array}{c}\text { Sumber } \\
\text { Sari }\end{array}$ & $\begin{array}{c}\text { Gedung } \\
\text { Jaya }\end{array}$ & $\begin{array}{c}\text { Rawa } \\
\text { Ragil }\end{array}$ & $\begin{array}{c}\text { Batu } \\
\text { Ampar }\end{array}$ \\
\hline $\begin{array}{c}\text { Specific weight } \\
(\mathrm{Gs})\end{array}$ & 2.68 & 2.52 & 2.43 & 2.43 & 2.29 \\
\hline $\begin{array}{c}\text { Unit weight } \\
\text { volume }\left(\mathrm{gr} / \mathrm{cm}^{3}\right)\end{array}$ & 1.60 & 1.39 & 1.31 & 1.32 & 1.35 \\
\hline $\begin{array}{c}\text { Mass density } \\
\left(\mathrm{gr} / \mathrm{cm}^{3}\right)\end{array}$ & 1.61 & 1.35 & 1.32 & 1.37 & 1.40 \\
\hline Pore number ('e) & 1.27 & 1.45 & 2.05 & 1.65 & 2.47 \\
\hline
\end{tabular}

Based on Table 2, it appears that the average volumetric shrinkage value of the sample is above $66.3 \%$. This is a significant change in soil volume compared to clay soils such as glacial fill, alluvial soil and Mio pliocene clays. The amount of linear shrinkage ranges from $16.36 \%$ $19.08 \%$. With this range of linear shrinkage values, all samples can be considered nearly uniform with the SC and $\mathrm{CH}$ soil classifications. This linear shrinkage will later be used to determine the magnitude of the flood embankment reduction. The magnitude of the ratio between volumetric shrinkage and the range of the initial water content to the water level of the shrinking limit (shrinkage ratio) has values ranging from 0.85 to 1.37 . The relationship of the magnitude of changes in this volume to the range of initial water content to the level of water shrinkage forming a regression equation for volumetric losses, namely $\mathrm{YV}=$ 27.144. $\ln (\mathrm{X})$ - 37.534, with a value of $\mathrm{R}^{2}=0.9783$. Another equation that is formed is for linear shrinkage, namely $\mathrm{YL}=4.1918 . \ln (\mathrm{X})-0.3953$ with a value of $\mathrm{R}^{2}=$ 0.9743. $\mathrm{X}$ itself is the range of initial water content to the limit of water content of shrinkage. In the form of a graph, the relationship is explained in the figure below.

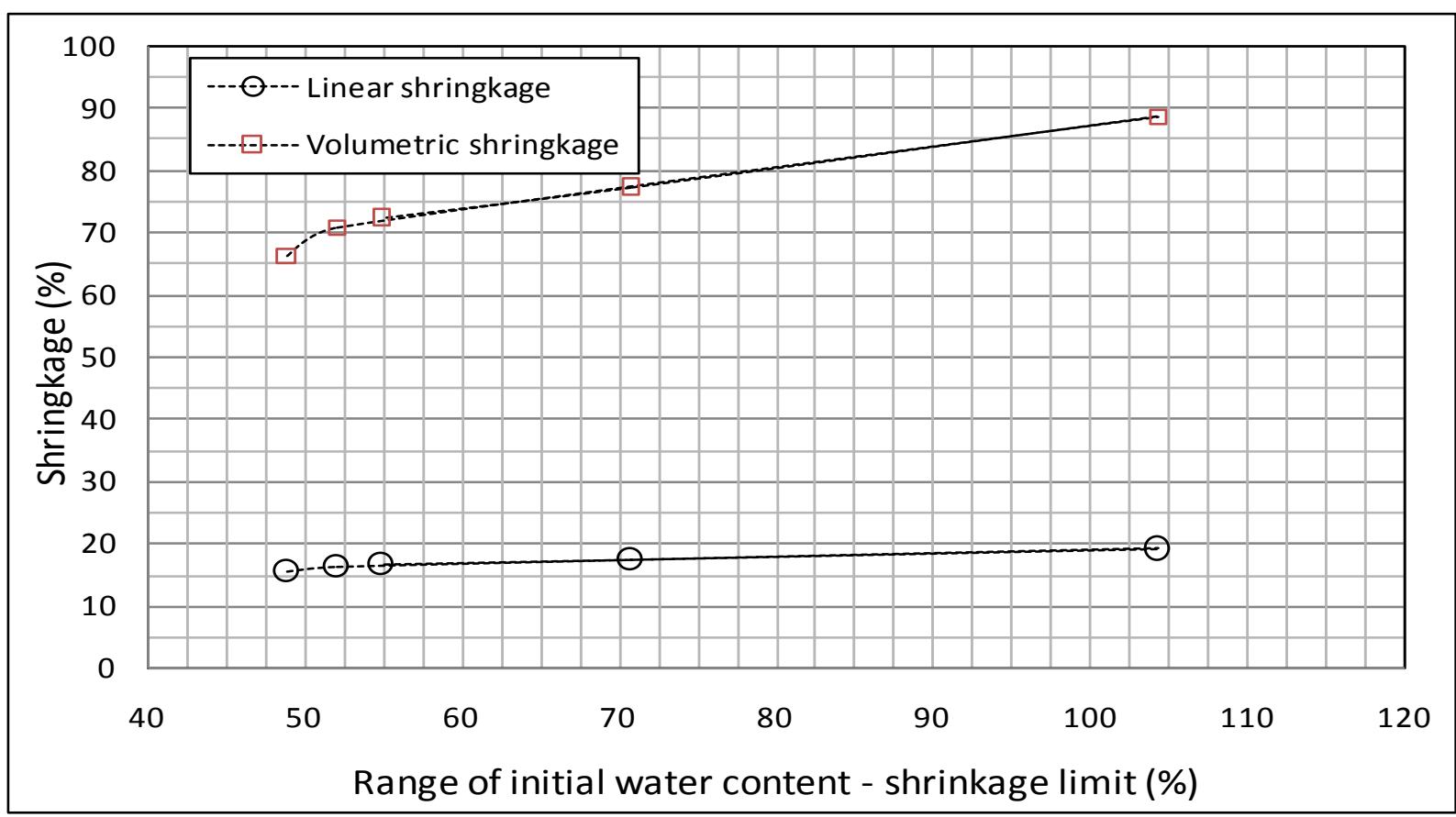

Figure 2. Shrinkage Vs range of initial water content - shrinkage limit 
Based on the graph above, it can be seen that the relationship between the change in linear shrinkage volume and the range of initial water content to the shrinkage limit gives a lower value compared to the relationship of the volumetric shrinkage change, which is around $20 \%$. This is because the linear shrinkage observed is only a change in one dimension that is only in the elongated direction.

\subsection{The Settlement of Flood Embankment}

The settlement that occurs due to linear shrinkage is obtained by multiplying the magnitude of the linear shrinkage to the initial embankment height for which data are obtained from the Public Works and Spatial Planning Office of Tulang Bawang Regency.
An immediate settlement, as in Equation 5 above, is obtained by multiplying the load, foundation width, Poisson number, foundation influence factor and divided by the young modulus value. Load evenly distributed is obtained by multiplying the volume unit weight by the height of the embankment.

In the consolidation test, the OCR value $<1$ means that both the embankment and the soil under the embankment experienced a decrease in consolidation. The magnitude of settlement is caused by consolidation on the embankment using Equation 6.

The value of soil consolidation under the embankment can be determined based on equation 7 , and the results are presented in Table 6.

Table 3. The calculation of settlement of embankment due to linear shrinkage

\begin{tabular}{ccccc}
\hline Sampling location & $\begin{array}{c}\text { Initial embankment height } \\
(\mathrm{cm})\end{array}$ & Linear shrinkage $(\%)$ & $\begin{array}{c}\text { The settlement due to } \\
\text { linear shrinkage }(\mathrm{cm})\end{array}$ & $\begin{array}{c}\text { Embankment height due to } \\
\text { linear shrinkage }(\mathrm{cm})\end{array}$ \\
\hline Aji Mesir & 150 & 15.59 & 23.39 & 126.62 \\
\hline Sumber Sari & 350 & 16.36 & 57.26 & 292.74 \\
\hline Gedung Jaya & 350 & 19.08 & 66.77 & 283.23 \\
\hline Rawa Ragil & 200 & 17.37 & 34.73 & 165.27 \\
\hline Batu Ampar & 180 & 16.58 & 29.85 & 150.15 \\
\hline
\end{tabular}

Table 4. The calculation of immediate settlement

\begin{tabular}{ccccccc}
\hline Sampling location & $\begin{array}{c}\text { Evenly distributed } \\
\text { load }(\mathrm{P})\left(\mathrm{gr} / \mathrm{cm}^{2}\right)\end{array}$ & $\begin{array}{c}\text { Foundation width } \\
(\mathrm{B})(\mathrm{cm})\end{array}$ & Ip & $\begin{array}{c}\text { Poisson } \\
\text { number }(\mu)\end{array}$ & $\begin{array}{c}\text { Young Modulus } \\
(\mathrm{E})\left(\mathrm{gr} / \mathrm{cm}^{2}\right)\end{array}$ & $\begin{array}{c}\text { Immediate } \\
\text { settlement }(\mathrm{cm})\end{array}$ \\
\hline Aji Mesir & 107.78 & 650 & 2.28 & 0.20 & $38,146.97$ & 8.93 \\
\hline Sumber Sari & 217.35 & 1,050 & 2.36 & 0.20 & $38,146.97$ & 13.6 \\
\hline Gedung Jaya & 213.68 & 1,050 & 2.36 & 0.20 & $38,146.97$ & 13.3 \\
\hline Rawa Ragil & 123.50 & 750 & 2.78 & 0.20 & $38,146.97$ & 6.5 \\
\hline Batu Ampar & 106.83 & 710 & 2.63 & 0.20 & $38,146.97$ & 5.0 \\
\hline
\end{tabular}

Table 5. Calculation of consolidation on embankments

\begin{tabular}{cccccc}
\hline Sampling location & $\begin{array}{c}\text { Initial embankment } \\
\text { height }(\mathrm{cm})\end{array}$ & $\begin{array}{c}\text { Initial pore value } \\
\left(\mathrm{e}_{0}\right)\end{array}$ & $\begin{array}{c}\text { Pore value due to } \\
\text { embankment load }\left(\mathrm{e}_{1}\right)\end{array}$ & $\Delta \mathrm{e}$ & $\begin{array}{c}\text { Settlement on embankments due } \\
\text { to consolidation }(\mathrm{cm})\end{array}$ \\
\hline Aji Mesir & 150 & 2.29 & 2.27 & 0.02 & 0.77 \\
\hline Sumber Sari & 350 & 2.57 & 2.44 & 0.13 & 12.89 \\
\hline Gedung Jaya & 350 & 2.74 & 2.62 & 0.12 & 11.21 \\
\hline Rawa Ragil & 200 & 2.39 & 2.36 & 0.03 & 1.62 \\
\hline Batu Ampar & 180 & 2.46 & 2.44 & 0.02 & 1.04 \\
\hline
\end{tabular}

Table 6. The settlement due to consolidation of soils under the embankments

\begin{tabular}{ccccccc}
\hline Sampling location & $\begin{array}{c}\text { The height of } \\
\text { soft soil }(\mathrm{H}) \text { in } \\
\mathrm{cm}\end{array}$ & $\begin{array}{c}\text { Load of } \\
\text { embankment }(\Delta \mathrm{P}) \\
\text { in gr/cm }\end{array}$ & $\begin{array}{c}\text { Load of soil under the } \\
\text { embankment }\left(\mathrm{P}_{0}\right) \text { in } \\
\left(\mathrm{gr} / \mathrm{cm}^{2}\right)\end{array}$ & $\left(\mathrm{C}_{\mathrm{c}}\right)$ & $\begin{array}{c}\text { Consolidation on the soil } \\
\left(\mathrm{e}_{0}\right)\end{array}$ & $\begin{array}{c}\text { under the embankment } \\
(\mathrm{cm})\end{array}$ \\
\hline Aji Mesir & 1.080 & 240 & 398.93 & 0.14 & 1.27 & 16.54 \\
\hline Sumber Sari & 1.140 & 486 & 356.22 & 0.08 & 1.45 & 9.04 \\
\hline Rawa Ragil & 1.820 & 264 & 490.37 & 0.17 & 1.65 & 40.23 \\
\hline Batu Ampar & 1.840 & 243 & 341.22 & 0.36 & 2.47 & 44.33 \\
\hline
\end{tabular}


If the total settlement due to linear shrinkage, immediate settlement and consolidation, compared to the settlement that occurred on the embankment in the field, there will be a uniform difference as in Table 7. This means that the results of the calculation of the settlement of embankment in the study area can be said to be close to the truth. (Quite different results were produced by sampling from Gedung Jaya. Therefore the calculation for the Gedung Jaya sample is not continued because it is considered as invalid data).

Figure 3 illustrate the contribution of each settlement in each sampling location.

The contribution of each type of settlement to the total embankment settlement is presented in Figure 5. The figure shows that the main cause of total settlement in the embankment is the settlement due to linear shrinkage. It contributes around $42.51 \%$ of total settlement. The next cause of the dike reduction is the consolidation of soil under the embankment, which contributes of $34.48 \%$ of total settlement. Furthermore, the cause of the settlement in the embankment was an immediate settlement which contributes around $18.32 \%$ of total settlement. The type of settlement that contributes the smallest to the total settlement of the embankment was the settlement of the embankment themselves, which was around $4.62 \%$ of total settlement.

Table 7. Difference of theoretical embankment height and real embankment height (field measurements)

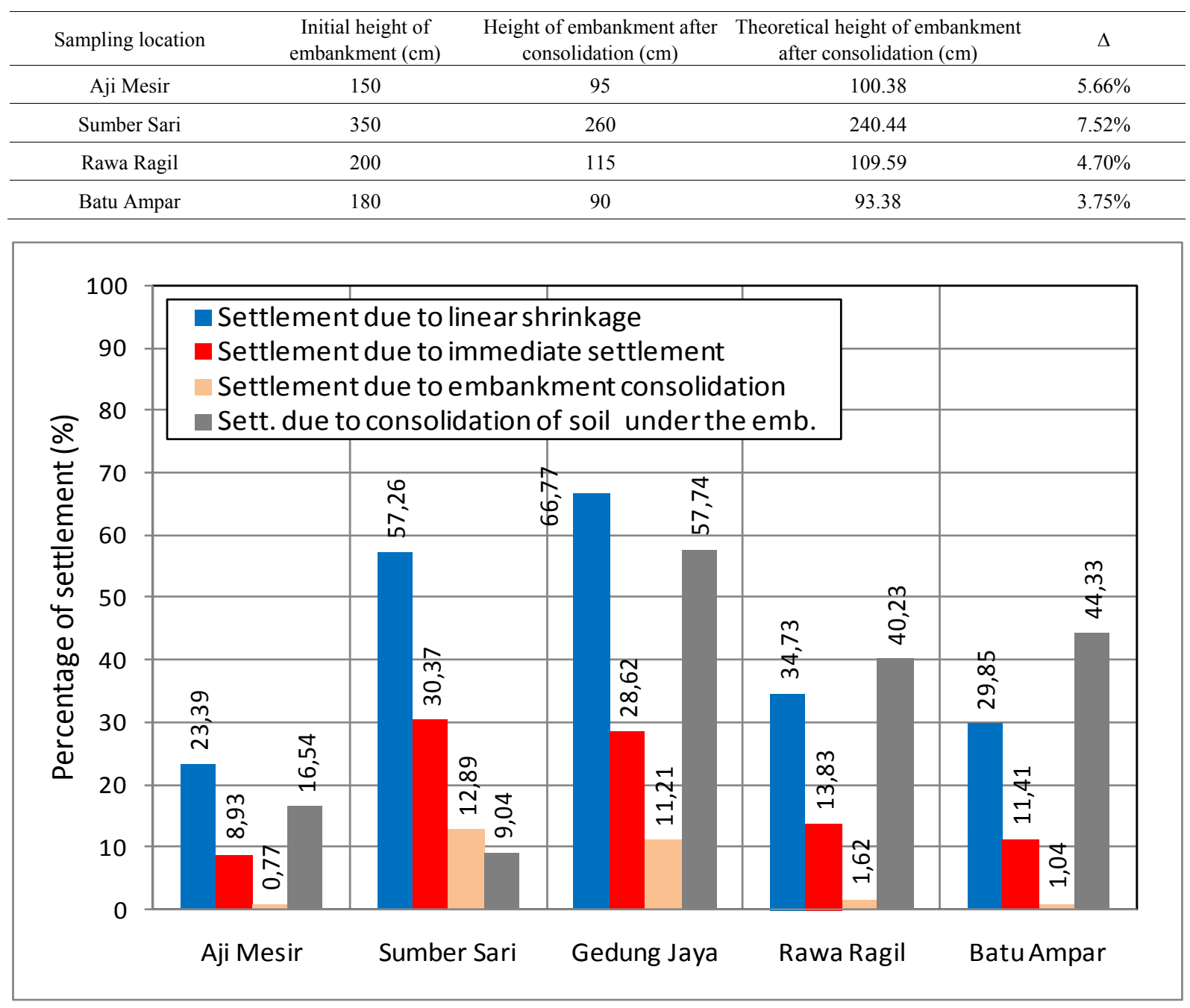

Figure 3. Contribution of each settlement to the total settlement in each sampling point 


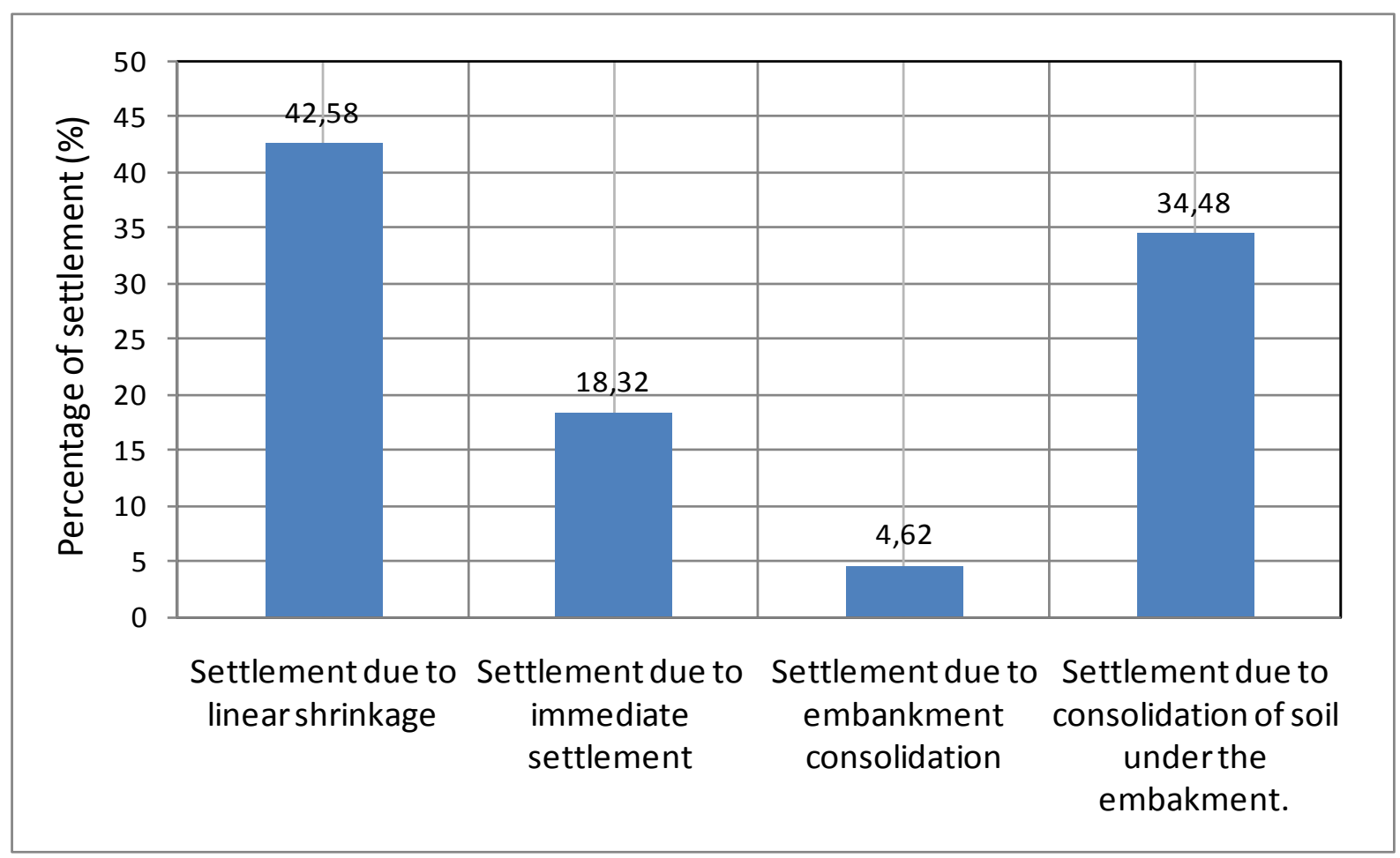

Figure 4. Contribution of each type of settlement to the total settlement

Table 8. Consolidation Time values based on the calculation

\begin{tabular}{|c|c|c|c|c|c|c|c|}
\hline \multirow[b]{2}{*}{$\begin{array}{l}\text { Sampling } \\
\text { location }\end{array}$} & \multicolumn{4}{|c|}{ Embankment } & \multicolumn{3}{|c|}{ Soil under the embankment } \\
\hline & $\begin{array}{c}\text { Embankment } \\
\text { height } \\
(\mathrm{cm})\end{array}$ & \multicolumn{2}{|c|}{ Consolidation $(\mathrm{cm})$} & $\begin{array}{l}\text { Time } \\
\text { (month) }\end{array}$ & $\begin{array}{c}\text { The depth } \\
\text { of soft soil }(\mathrm{cm})\end{array}$ & Consolidation $(\mathrm{cm})$ & $\begin{array}{l}\text { Time } \\
\text { (month) }\end{array}$ \\
\hline Aji Mesir & 150 & \multicolumn{2}{|l|}{0.77} & 1.30 & 1,080 & 16.54 & 22.45 \\
\hline Sumber Sari & 350 & \multicolumn{2}{|l|}{12.89} & 1.82 & 1,140 & 9.04 & 5.25 \\
\hline Rawa Ragil & 350 & \multicolumn{2}{|l|}{1.62} & 0.58 & 1,980 & 40.23 & 12.04 \\
\hline Batu Ampar & 200 & \multicolumn{2}{|l|}{1.04} & 1.12 & 1,820 & 44.33 & 29.15 \\
\hline $\begin{array}{l}\text { Sampling } \\
\text { location }\end{array}$ & $\begin{array}{l}\text { Existing } \\
\text { embankment } \\
\text { height } \\
(\mathrm{cm})\end{array}$ & $\begin{array}{l}\text { Theoretical } \\
\text { embankment } \\
\text { height } \\
(\mathrm{cm})\end{array}$ & $\Delta(\%)$ & $\begin{array}{r}\text { Th } \\
\text { for } \\
\text { (obser }\end{array}$ & $\begin{array}{l}\text { time needed } \\
\text { consolidation } \\
\text { ations) (month) }\end{array}$ & $\begin{array}{l}\text { The time needed } \\
\text { for consolidation } \\
\text { (calculation) } \\
\text { (month) }\end{array}$ & $\begin{array}{l}\text { onsolidation time } \\
\quad \text { T90 }\end{array}$ \\
\hline Aji Mesir & 127.32 & 132.70 & $4.22 \%$ & & 67 & 22.45 & Reached \\
\hline Sumber Sari & 347.63 & 328.07 & $5.63 \%$ & & 44 & 5.25 & Reached \\
\hline Rawa Ragil & 163.56 & 158.15 & $3.31 \%$ & & 40 & 12.04 & Reached \\
\hline Batu Ampar & 131.25 & 134.63 & $2.57 \%$ & & 17 & 29.15 & Unreached \\
\hline
\end{tabular}

\subsection{The Settlement of Flood Embankment}

The time of consolidation is the time required for the soil to become compressed by removing the soil pore water due to loading. The time of consolidation of the embankment and the underlying soil is calculated based on equation 7 and is presented in Table 8. Based on Table 8 , it can be seen that the consolidation time occurring on the embankment is much shorter, which ranges from 0.58 to 1.82 months, when compared to the consolidation time on land under the embankment, which is between 5.25 and 29.15 months. This may occur due to the height of the embankment layer is shorter when compared to the one of the underlying soil layers.

In order to find out whether the current dike has reached its consolidation time, we need to compare the time span since the dike was made with its consolidation time. Based on Table 9, it appears that the consolidation process has 
been completed on the embankment Aji Mesir, Sumber Sari, and Rawa Ragil. On the other hand, the consolidation process at the Batu Ampar embankment is still in process.

A decrease in embankment due to linear shrinkage and an immediate decrease are assumed to occur simultaneously and occur immediately since the embankment was made. Whereas the decrease of embankment and the soil under the embankment due to its consolidation will follow the time of its consolidation, although actually the soil will continue to become incompressible in its secondary consolidation which is smaller and slower, until it reaches plastic deformation of soil particles. The ratio between the percentage of embankment reduction and time in the Rawa Ragil and Batu Ampar areas is greater than the one in Aji Mesir and Sumber Sari. This might have happened because Rawa Ragil and Batu Ampar are located in the downstream area which has deeper soft soil layers, which is between 1.82 to
$1.84 \mathrm{~m}$. While Aji Mesir Aji Region and Sumber Sari are located in the upper reaches of the river which has a depth of soft soil layers between 1.08 to 1.14 meters. This condition results in two types of curve of ratio between the percentage of embankment reduction and time, for sampling locations in the upstream and downstream area of the river as illustrated in Figure 5. The curves are produced by regression equation as follows:

$\mathrm{Y}_{1}=0,0163 \cdot \ln (\mathrm{x})+0,2703$ for upstream area

$\mathrm{Y}_{2}=0,0512 \cdot \ln (\mathrm{x})+0,2987$ for downstream area with,

$\mathrm{Y}_{1}$ : ratio between existing height of embankment to the initial height of embankment for area located in upstream of the river (\%).

$\mathrm{Y}_{2}$ : ratio between existing height of embankment to the initial height of embankment for area located in upstream of the river (\%).

$\mathrm{X}$ : time of consolidation (month)

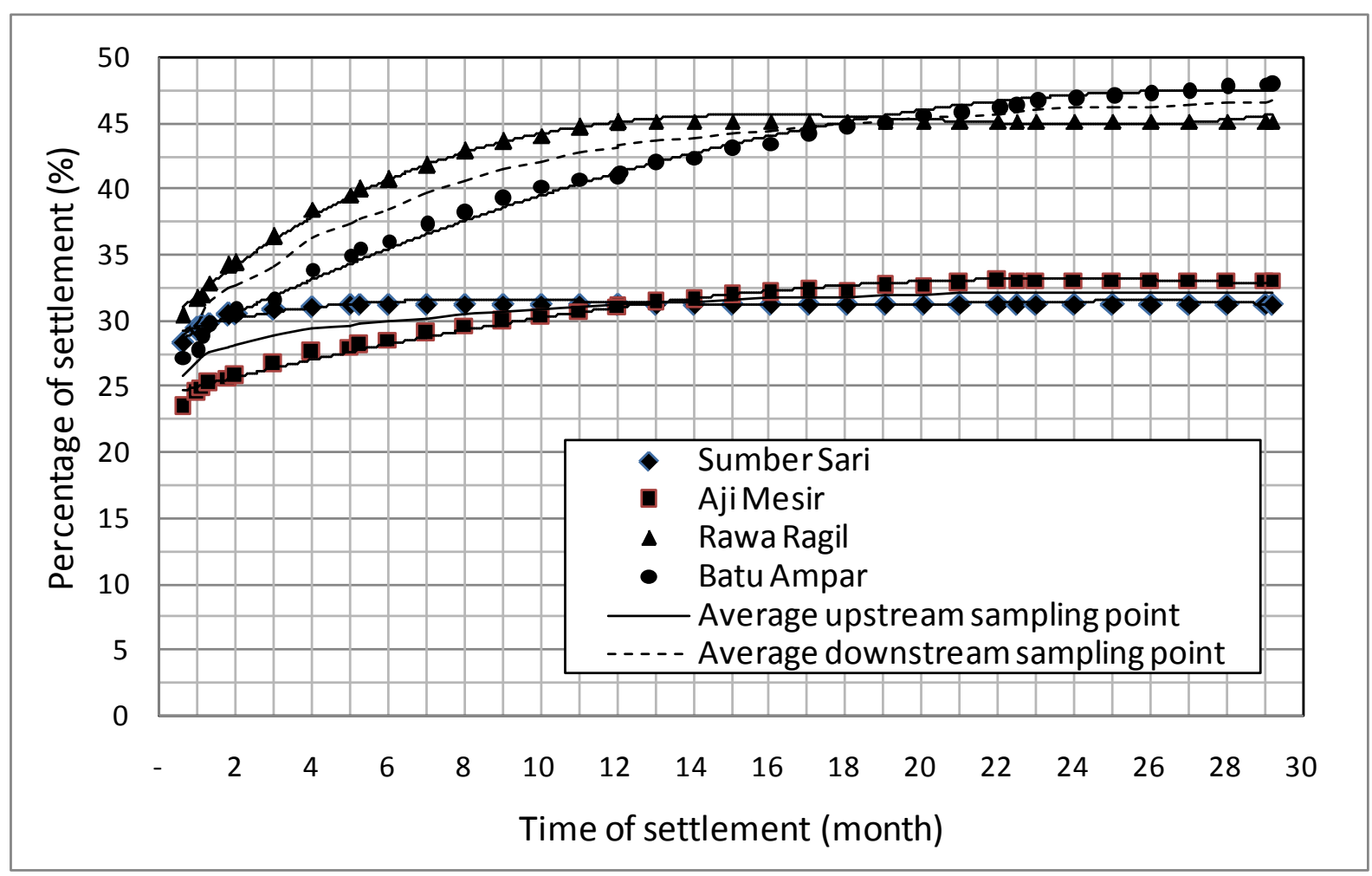

Figure 5. Relationship of the percentage of settlement and time 


\section{Conclusions}

Case studies of embankment decline in swampy areas due to shrinkage and consolidation in the Tulang Bawang watershed have been investigated and analyzed. The study provides the following conclusions:

1. Linear shrinkage contributes between $16.36 \%-19.08 \%$ of the total decrease. This range of linear shrinkage occurs in all types of soil. The value of reduction based on calculations due to linear shrinkage in embankment samples in the field ranged from 23.39 $66.77 \mathrm{~cm}$.

2. The relationship between changes in the linear direction (YL) with the difference between the water content of the shrinkage limit and the initial water content $(\mathrm{X})$ forms a regression equation $\mathrm{YL}=4.1918$. $\ln (\mathrm{X})-0.3953$ with a value of $\mathrm{R}^{2}=0.9743$.

3. Linear shrinkage gives the biggest contribution in decreasing total embankment. Next in a row, from large to small, is the consolidation of land under the embankment, immediate decline, and consolidation on the embankment.

4. The time of consolidation on embankments is much shorter than the time of consolidation of soils under embankments. The relationship between the percentage of embankment decreases with time is stated by the regression equation as follows:

$\mathrm{Y} 1=0.0163 . \ln (\mathrm{x})+0.2703$ for the sample location in the upper river area.

$\mathrm{Y} 2=0.0512 . \ln (\mathrm{x})+0.2987$ for the sample location downstream of the river.

dengan:

$\mathrm{Y}$ is the ratio between the percentage of embankment reduction to the height of the initial embankment and $\mathrm{x}$ is the time of decline (month).

\section{Acknowledgements}

The authors would like to express their highest gratitude and appreciation to the Civil Engineering Faculty of Lampung University and to the Lab technicians for their help and support in the implementation and completion of this paper.

\section{REFERENCES}

[1] Afriani L, Adha I, Juansyah Y, Febrina R. Modification Compression Strength of Test Machine by Using Control System on Compaction Energy. Proceeding of International Conference on Engineering Science and Technology (ICEST); 2008 June 25-26; Bandar Lampung, Indonesia. IOP Conference Series.

[2] Afriani, L. Soil Shear Strength, Jakarta: Graha Ilmu Publisher; 2014.

[3] Kumor MK. Selected geotechnical problems of expansive clays in the area of Poland. Archit Civil Eng Environ, 2008, 1(4):75-92.

[4] Izdebska- Mucha, D. and Wójcik, E. Testing shrinkage factor: comparison of methods and correlation with indeks properties. Bulletin of Engineering Geology and the Environment. 2013, 72: 15-24.

[5] Muntohar, AS. Introduction to Geotechnique. Yogyakarta: University Muhammadiyah Jogja Soil Mechanics Lab.; 2005.

[6] Das, BM. Soil Mechanic, Geotechnique Principle. Jakarta: Erlangga; 1995.

[7] Public Works and Spatial Planning Office, Tulang Bawang Regency. Data Base Jaringan Irigasi Rawa Kabupaten Tulang Bawang. Tulang Bawang: Water Resources Division; 2016.

[8] Soil Survey Division Staff. Soil Survey Manual: US Dept. Agriculture Handbook No. 18. Washington DC: United State Department of Agricultural; 1993

[9] Ministry of Settlement and Regional Infrastructure of the Republic of Indonesia. Process of formation and basic properties of soft soil. Bandung: Guidelines for Regional Infrastructure Research and Development Center No: Pt T-8-2002-B; 2002. 